\title{
Monitoring and Controlling Mastitis on Ontario Dairy Farms
}

\author{
Wayne H. Howard, ${ }^{1}$ Ravinderpal Gill, ${ }^{2}$ Kenneth E. Leslie ${ }^{3}$ and \\ Kerry Lissemore \\ ${ }^{1}$ Associate professor, Department of Agricultural Economics \\ and Business, University of Guelph, Guelph, Ontario. \\ ${ }^{2}$ Research associate, Department of Agricultural Economics \\ and Business, University of Guelph, Guelph, Ontario. \\ ${ }^{3}$ Associate professor, Department of Population Medicine, \\ University of Guelph, Guelph, Ontario. \\ ${ }^{4}$ Assistant professor, Department of Population Medicine, \\ University of Guelph, Guelph, Ontario.
}

The frequency of use and the marginal costs and marginal value products of mastitis control practices on somatic cell count (SCC) and milk yield are investigated. A survey of current management practices is combined with Dairy Herd Improvement production information to determine the relationships between milk yield, SCC, management practices, and production and producer characteristics under field conditions. The relationships are modeled and compared at the cow and herd level. A moment-generating approach is used in the herd model to determine which, if any, practices are risk reducing. The SCC for an individual cow is a better indicator of milk production lost due to mastitis than is a bulk tank SCC. Most recommended mastitis control practices are estimated to be economically beneficial, but some common practices are found not to be economical, and questions are raised about dry cow treatment.

On a examiné la fréquence à laquelle on recourt aux pratiques de lutte contre la mammite, de même que les coûts et les avantages marginaux de ces dernières en ce qui concerne la numération des cellues somatiques et le rendement laitier. On a combiné une enquête sur les pratiques zootechniques actuelles aux renseignements sur la production extraits du Programme d'amélioration des troupeaux laitiers en vue de déterminer les relations qui existent entre le rendement laitier, la numération des cellules somatiques, la conduite du troupeau ainsi que les caractéristiques associées à la production et aux producteurs, sur le terrain. On a ensuite modélisé ces relations et on les a comparées entre les animaux et les troupeaux. Pour le modèle touchant les troupeaux, on s'est servi d'une approche générant des moments, pour déterminer si une pratique quelconque diminuait les risques. La numération des cellules somatiques chez la vache est un meilleur indicateur du volume de lait perdu à la suite de la mammite que la numération des cellules somatiques dans la citerne. La plupart des méthodes de lutte contre la mammite recommandées offrent un avantage économique, mais certaines pratiques courantes ont l'effet contraire et on s'interroge sur l'utilité de traiter les vaches taries. 


\section{INTRODUCTION}

Estimates of the loss due to mastitis on dairy farms are important because they are the basis for cost-effective mastitis control and prevention strategies. Several recommended control practices have been found to have substantial returns over costs in controlled experiments (Natzke 1981; Philpot 1984). However, experimental results and the results producers obtain in the field can be substantially different (Dillon 1977). Moreover, differences in herd size, environmental conditions and production systems (e.g., pipeline versus milking parlor) can yield different marginal effects of various control practices on udder health and, subsequently, udder health on milk yield. Therefore, a "farm trial" under field conditions is the preferred way to evaluate the efficacy and cost effectiveness of mastitis control practices.

The purpose of this study is to determine the costs and benefits of various mastitis control practices. Specific objectives are:

- to determine the frequency of use of recommended mastitis management practices on Ontario dairy farms;

- to estimte the statistical relationship between management practices, somatic cell count $(\mathrm{SCC})^{1}$ and milk yield; and

- to estimate the expected marginal costs and marginal returns for the various management practices.

Individual cows are the basic production unit on a dairy farm, but several management decisions that affect individual cows are made at the herd level. Moreover, monitoring of production and health indicators such as the SCC is often done at the herd level. A further objective of this study is to determine whether the relationship between milk yield, SCC and management practices is different when modeled at the herd level as opposed to the individual cow level. Furthermore, given the stochastic nature of production agriculture, management practices have uncertain returns. ${ }^{2}$ A practice administered at the herd level may or may not affect an individual cow in the expected manner. It is possible for a practice to reduce the occasional mastitis flare-up and corresponding high SCC while not affecting the herd's mean SCC. In effect, such a practice could reduce risk but not affect expected (mean) output. Therefore, a flexible moment-based approach is used to determine whether particular management practices are risk reducing in that they affect more than one moment of the SCC or milk yield distribution.

Recommended mastitis control practices and previous research on mastitis are briefly discussed in the following section. Next, the flexible moment-based approach is discussed as a way to model the relationship between milk yield, SCC and management practices. The results of a survey of dairy producers in Ontario is then presented, along with the results of models of milk yield and SCC estimated at the individual cow level and at the herd level. A discussion and summary end the paper. 


\section{MASTITIS AND MILK YIELD}

Mastitis is a general term referring to an inflammation in a mammary gland, Mastitis costs dairy producers in terms of decreased production, medicine costs, treatment time and premature culling (Natzje 1976). Clinical mastitis is a clearly apparent infection, while subclinical mastitis is non-symptomatic yet accounts for about $70 \%$ of the milk loss on dairy farms due to mastitis (Kirk and Bartlett 1988). Subclinical mastitis being non-symptomatic means that many dairy producers suffer losses without being aware of the problem. A quick and efficient indicator of a subclinical infection is the SCC. It is well documented that there is a negative relationship between milk yield and SCC (e.g., Jones et al 1984). A high SCC also lowers milk quality and dairy product yields (Smith 1988).

Management practices that minimize the occurrence of clinical mastitis and decrease the level of subclinical mastitis will increase milk yields and revenues for dairy producers. The U.S. National Mastitis Council and most Canadian dairy extension programs recommend a mastitis control program consisting of hygienic washing and drying of udders before milking, regular milking-machine maintenance, teat dipping after milking, antibiotic therapy on all cows at drying off (dry cow treatment), culling cows with chronic mastitis and milking infected cows last (Philpot 1984). ${ }^{3}$ Economic studies of these recommended practices in controlled experiments have found them to have substantial returns over costs (Natzke 1976). However, results under field conditions have had unexpected results for some practices and have raised questions about the efficacy of those practices (Howard et al 1987).

Previous mastitis studies have estimated the relationship between milk production and mastitis based upon single-equation estimation of milk yield and either the California Mastitis Test (CMT) or the SCC as an indictor of infection. ${ }^{4}$ All the studies estimated a clearly negative relationship between milk yield and CMT or SCC, but the estimated average milk loss due to mastitis has a broad range, as reported from number of selected studies in Table 1. A few studies also estimated the loss due to mastitis from discarded milk, the cost of drugs, veterinary services and labour, and culling, but the greatest loss is from decreased yields (Natzke 1976; Morse et al 1987; Kirk and Bartlett 1988).

A shortcoming of the single-equation models is that they model milk yield as a function of SCC or CMT results but do not explicitly recognize the relationship between milk yield, SCC and management practices. If milk yield is a function of SCC and SCC is a function of management practices, then there is contemporaneous correlation between milk yield and SCC and they should be modeled as a system. Howard et al (1987) recognized that contemporaneous correlation and modeled milk yield as a function of SCC and several producer and production characteristics and SCC as a function of management practices and producer and production characteristics; i.e., SCC was modeled as jointly dependent. Moreover, they used survey data that in effect were a farm trial. Their results for some 
Table 1. Estimated losses in milk yield attributed to mastitis

\begin{tabular}{lcc}
\hline Study & Measure & Milk loss \\
\hline Appleman et al (1965) & CMT $^{\text {d }}$ & $0.41-3.08 \mathrm{~kg} /$ cow $/$ day \\
Batra (1986) & SCC $^{b}$ & $2.3-3.2 \mathrm{~kg} /$ cow $/$ day \\
Dohoo et a! (1984) & LSCC $^{\mathrm{c}}$ & $0.65-1.44 \mathrm{~kg} / \mathrm{cow} /$ day \\
Forester et al (1967) & CMT $^{\prime}$ & $0.35-2.66 \mathrm{~kg} / \mathrm{qtr} /$ day \\
Howard et al (1987) & SCC & $6.8-7.26 \mathrm{~kg} /$ cow $/$ day \\
Jones et al (1984) & SCC & $1.3-3.0 \mathrm{~kg} /$ cow $/$ day \\
Robertas and Shook (1982) & LSCC & $0.44-0.89 \mathrm{~kg} /$ cow $/$ day \\
Salsberg et al (1984) & SCC & $0.65 \mathrm{~kg} / \mathrm{cow} /$ day \\
Tyler et al (1989) & BT-SCC & $3.0-22.0 \mathrm{~kg} / \mathrm{cow} /$ day \\
\hline
\end{tabular}

${ }^{a}$ California mastitis test

${ }^{\mathrm{b} C C}$ measured in log base 2, and an increase in SCC score from zero to five "natural logarithm SCC

bulk tank SCC

recommended and widely adopted practices were different from those obtained from controlled experiments, raising questions about the efficacy of those practices under field conditions.

\section{METHODS}

To meet the objectives of the study, Ontario dairy producers were surveyed to determine current management practices. The survey data were combined with respective Ontario Dairy Herd Improvement Corporation (ODHIC) production data to estimate the relationships between milk yield, SCC, management practices, and producer and production characteristics. Milk yield and SCC are estimated as a system because of their well-known but not clearly understood relationship. The model estimate is:

$$
\begin{gathered}
M K G=f\left(S C C, S C C^{2}, P_{i}\right) \\
S C C=g\left(M_{i}, P_{i}\right)
\end{gathered}
$$

Test day milk yield, $M K G$, is estimated in a quadratic form of SCC to allow for increasing and decreasing responses. The SCC in the model is the log base 2 score reported in integers to the producer. The production characteristics, $P_{i}$, are those commonly used to describe and differentiate herds. Management practices, $M_{i}$, are those mentioned in the literature as likely affecting the SCC. The SCC score is a joinly dependent variable, so instruments for it are estimated using the management practices and producer and production characteristics. 
The management practices and production characteristics included in the model are described in Table 2 . The practices enter the model as binary variables (i.e., $M_{i}=1$ if the $i$ th practice is employed; otherwise $M_{i}=0$ ). Continuous producer and production variables enter at their respective values. Most dairy production studies account for unobservable differences across herds with binary dummy variables. The mix of management practices and herd and producer characteristics is assumed to account for most of the differences across herds that are usually unobserved. Consequently, herd dummy variables are not included in this model.

Collinearity is examined through the condition index and the correlation matrix of the exogenous variables. If two or more variables are found to be highly correlated, one or more are excluded from the final model. The variables retained in the model are selected based upon technical relationships and the mean square error of the remaining coefficients; e.g., given two technically similar practices that are highly correlated, the one with the least effect on the estimated mean square error is deleted.

The effect of a managment practice on milk yield is obtained by determining the effect of SCC on milk yield and the effect of the practice on SCC. Variables in the milk yield equation are set at their mean values and the SCC score varied from 0 to 9 . The resulting values are in effect a loss function that reports milk loss due to increasing SCC as a percentage of potential production. Similarly, the marginal product of a management practice on SCC is obtained by setting variables at their expected values (continuous variables at their means and binary variables according to frequency) and determining the effect of the practice in question on the SCC. Hence, the estimated model allows one to determine change in SCC due to using a management practice and the change in milk yield due to the change in SCC.

The economic benefits of selected management practices are evaluated under current fluid milk prices and under a proposed multiple-component pricing system to see how sensitive the marginal value products (MVPs) of the practices are to different pricing systems. The MVP of a management practice is computed by multiplying the difference between milk yield with and without the practice times the price of class 1 milk for southern Ontario $(\$ 54.45$ per hectolitre in November (1988) ceteris paribus. The marginal input costs (MICs) of selected practices are obtained from a survey of the producers. Under the proposed multiple-component pricing (MCP) system, prices for fat and solids-not-fat (SNF) are $\$ 5.247$ and $\$ 2.3864$ per kilogram, respectively. Fat and SNF are substituted for $M K G$ in the milk yield Eq. 1 and the effect of a management practice on each component is computed as previously outlined. Fat yields are obtained from the ODHIC records. Lactose and mineral quantities are used to calculate SNF, based on the 1987-88 provincial average of 5.8 kilograms per hectolitre (OMMB 1985).

Given that most management practices are administered at the herd level and that many producers monitor their SCC at the herd level, the effect of management 
Table 2. Description, frequency and mean of selected management practices and production characteristics. Ontario dairy farms, 1988

\begin{tabular}{llll}
\hline Variable & Description & \% frequency & Mean \\
\hline
\end{tabular}

Feeding and bedding practices:

M1 Number of cows per box stall

$M 2 \quad$ Straw used for bedding

85.4

M3 Use a lot of bedding

28.8

M4 Percentage forage purchased

M5 Percentage grain purchased

\section{Washing practices:}

M6 Individual paper towels $\quad 45.0$

$\begin{array}{lll}M 7 & \text { Individual newspapers } & 28.7\end{array}$

$\begin{array}{lll}M 8 & \text { Reusable sponge/cloth } & 14.9\end{array}$

M9 Hand-held sprayer 4.1

$M 10 \quad$ Sanitizer used in the washing solution 91.1

Drying practices:

$\begin{array}{ll}M 11 \quad \text { Udders always dried } & 57.7\end{array}$

$\begin{array}{lll}M 12 & \text { Single-use paper towels } & 39.9\end{array}$

$M 13 \quad$ Reusable sponge/cloth $\quad 6.3$

M14 Newspapers $\quad 32.2$

\section{Other practices:}

M15 Milking-machine inflations changed as needed

M16 Iodine predip used

$M 17 \quad$ Strip cup used for premilking check

M18 Premilking check done onto a paper towel

M19 Do nothing if abnormal milk is discovered $\quad 81.7$

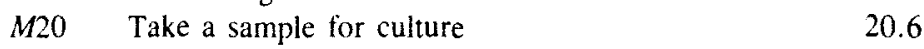

$M 21$ Treat the cow with antibiotics 75.3

M22 Dip teats after milking 91.5

M23 Use dry cow treatment on all cows $\quad 65.6$

M24 Use dry cow treatment on selected cows only 28.2

M25 Use dry cow treatment on high SCC cows only 41.5

M26 Use dry cow treatment on cows treated during the lactation only

M27 Use dry cow treatment on older cows only 1.3

M28 Vet involved in regular mastitis control program $\quad 25.0$

M29 OMMB udder health specialist visited the farm 53.6

M30 Emergency/acute cases and moderate cases that do not respond to own treatment brought to the attention of the vet

M31 Chronic clots/flare-ups brough to attention of vet 
Table 2. Continued

\begin{tabular}{|c|c|c|c|}
\hline Variable & Description & $\%$ frequency & Mean \\
\hline M32 & Increased SCC brought to the attention of vet & 11.9 & \\
\hline M33 & Consider mastitis when cull cows & 89.5 & \\
\hline M34 & Ranking of mastitis as a basis for culling & & 3.12 \\
\hline$M 35$ & Stated SCC level a cow consistently has for culling & & 6.00 \\
\hline \multicolumn{4}{|c|}{ Production and producer characteristics: } \\
\hline$P 1$ & Owner does most of milking & 49.6 & \\
\hline$P 2$ & Employees do most milking & 17.6 & \\
\hline$P 3$ & Number of different milkers per week & & 1.8 \\
\hline$P 4$ & Age of owner/operator & & 45.02 \\
\hline P5 & Years in dairy farming & & 25.28 \\
\hline P6 & Years managing own dairy farm & & 18.20 \\
\hline$P 7$ & Years in school & & high school \\
\hline$P 8$ & Number of people working on the dairy farm & & 3.39 \\
\hline P9 & $\begin{array}{l}\text { Owner now and then attends dairy extension } \\
\text { seminars }\end{array}$ & 49.2 & \\
\hline$L N$ & Lactation number & & 2.69 \\
\hline$S L 2$ & 3 rd- -5 th month of lactation & 38.2 & \\
\hline SL3 & 6th and later month of lactation & 58.0 & \\
\hline NOC & Number of cows in the herd & & 55.00 \\
\hline$B H$ & Breed other than holstein & 8.3 & \\
\hline$B C A M^{\mathrm{a}}$ & Breed class average milk $(\mathrm{kg})$ & & 152.22 \\
\hline$B C A P^{a}$ & Breed class average fat $(\mathrm{kg})$ & & 153.00 \\
\hline$B C A F^{\mathrm{a}}$ & Breed class average protein $(\mathrm{kg})$ & & 152.63 \\
\hline$P L 2$ & Percentage of herd in lactation 2 & & 45.69 \\
\hline$P L C$ & Plate loop count & & 8809.33 \\
\hline PSL2 & Percentage of herd in 1st stage of lactation & & 30.40 \\
\hline PSL3 & Percentage of herd in 2 nd stage of lactation & & 33.63 \\
\hline$S C C$ & SCC score & & 3.05 \\
\hline$S C C^{2}$ & SCC score squared & & \\
\hline
\end{tabular}

${ }^{a}$ Breed class average milk (fat and protein, respectively) is a standardized index of milk production ( $1950=100$ ) corrected by breed, season of calving and age at calving. It is approximately equivalent to the 305-day milk equivalent, but is listed as an index rather than as a quantity.

practices on the distribution of milk yield and SCC is examined using the flexiblemoments approach (Antle 1983). The flexible-moments approach allows determination of risk-reducing management practices that cannot be identified by examining the expected (mean) effect of the practice.

The moments-based approach provides a statistical methodology for estimating the mean and higher moments of output as functions of inputs. It is motivated by the facts that the probability distribution of output is a unique function of 
its moments and that the output distribution can be approximated to the $n$th degree using the first $n$ moments of the distribution. Thus, the moments of the probability distribution of output can be used to uniquely identify and approximate the stochastic structure of technology. The approach is flexible in that the moments-of-output distribution can be modeled as linear functions of the inputs and it does not impose restrictions on the effects of inputs either within or across moments. The effects of an input on output can be independent across moments; e.g., an input may have no effect on the mean but could affect the variance and the skewness.

The moments-based approach employs a linear moments model (LMM), which is a general representation of the output distribution and is sufficiently general for testing restrictions on the moment function parameters within and across equations. Least squares estimates of the LMM parameters are consistent but biased because the variance of the second or higher moment is a function of the parameters of the first (and subsequent) moments, and hence heteroskedastic. However, the least squares estimates are consistent; thus they can be used to weight a generalized least squares (GLS) estimator. The weighted GLS estimators are asymptotically equivalent to the true GLS estimators and are asymptotically normally distributed. Hence, standard large sample statistics can be used for hypothesis testing (Antle 1987).

\section{RESULTS}

\section{Data}

Approximately $70 \%$ of Ontario's 9,600 dairy herds enrolled in ODHIC in 1988; $52 \%$ of those enrolled in ODHIC chose the SCC option, which reports the SCC for individual cows. From that group, 1,200 were randomly surveyed by mail in November 1988, and 719 returned a completed questionnaire and a letter releasing their ODHIC records. ${ }^{5}$

The potential for selection bias exists. Compared with the provincial average, the producers surveyed had larger herds (55 versus 44 cows), higher milk production $(6,673$ versus 5.719 litres per lactation and lower SCC $(245,000$ versus 353,000 cells per millilitre in the bulk tank). This group's expressed interest in SCC may be an indicator that they are more aware of mastitis and mastitis-control methods than is the population of all producers. There is also potential bias since they were on ODHIC, which is itself optional. However, enrollment in DHI programs is so common that any bias by being enrolled in ODHIC is likely unimportant.

\section{Management Practices}

The description, frequency and mean of selected management practices and producer and production characteristics are listed in Table 2. The majority of the producers followed many of the recommend practices, but only a third of them used all five practices recommended by the U.S. National Mastitis Council 
(i.e., washing and drying udders before milking, teat dipping, dry cow treatment, and considering mastitis when culling). There were still 5.3\% who did not wash udders before milking, $27.1 \%$ who did not dry udders before milking, $8.5 \%$ who did not dip teats, $34.4 \%$ who did not routinely treat cows with antibiotics at the end of a lactation (dry cow treatment) and $10.5 \%$ for whom mastitis was not a culling criteron. These precentages are somewhat surprising, given that one would expect this sample to have a high level of awareness about mastitis prevention and control.

\section{Milk Yield and SCC}

Parameter estimates and standard errors for the cow model and the first three moments of the herd model are report in Table 3 . The models explain $38 \%$ of the variation in milk yield and SCC in the cow model, and 69\%, 10\% and 56\% of the variation in average milk yield and SCC in the first, second, and third moments of the herd model, respectively.

Table 3. Estimated 3SLS model of milk yield, somatic cell count, management practices and producer and production characteristics

\begin{tabular}{|c|c|c|c|c|}
\hline \multirow{2}{*}{$\begin{array}{c}\text { Independent } \\
\text { variable }^{\mathrm{a}}\end{array}$} & \multirow[b]{2}{*}{ Cow model } & \multicolumn{3}{|c|}{ Herd model } \\
\hline & & Mean & Variance & Skewness \\
\hline \multirow[t]{2}{*}{ Intercept } & $12.551 * * *$ & $4.818 * * *$ & 0.225 & $0.344 * *$ \\
\hline & $(2.706)$ & $(0.362)$ & $(0.225)$ & $(0.125)$ \\
\hline \multirow[t]{2}{*}{$S C C^{b}$} & $-1.531^{* * *}$ & 1.251 & 4.906 & $-71.406^{*}$ \\
\hline & $(0.101)$ & $(0.895)$ & $(4.266)$ & $(40.471)$ \\
\hline \multirow[t]{2}{*}{$S C C^{2}$} & $0.081 * * *$ & $-0.251 * *$ & $-5.454 * * *$ & 7.002 \\
\hline & $(0.013)$ & $(0.117)$ & $(0.563)$ & $(5.770)$ \\
\hline \multirow[t]{2}{*}{$L N$} & $1.176^{* * *}$ & -1.409 & 8.499 & $-297.233 * * *$ \\
\hline & $(0.027)$ & $(2.819)$ & $(11.550)$ & $(102.534)$ \\
\hline \multirow[t]{2}{*}{$S L 2$} & $-5.781 * * *$ & $16.493 * * *$ & -10.193 & $444.387 * * *$ \\
\hline & $(0.136)$ & $(2.432)$ & $(13.329)$ & (136.144) \\
\hline \multirow[t]{2}{*}{$S L 3$} & $-13.698 * * *$ & $4.319^{*}$ & -3.953 & 174.161 \\
\hline & $(0.140)$ & $(2.284)$ & $(12.645)$ & $(131.144)$ \\
\hline \multirow[t]{2}{*}{$N O C$} & $0.005^{* *}$ & $0.038 * * *$ & -0.095 & $1.015^{*}$ \\
\hline & $(0.007)$ & $(0.010)$ & $(0.053)$ & $(0.569)$ \\
\hline \multirow[t]{2}{*}{$B H$} & $-0.834 * *$ & & & \\
\hline & $(0.456)$ & & & \\
\hline \multirow[t]{2}{*}{$B C A$} & $0.130 * * *$ & & & \\
\hline & $(0.003)$ & & & \\
\hline \multirow[t]{2}{*}{$P L C$} & & $0.00005^{* * *}$ & $0.0001 * * *$ & 0.0009 \\
\hline & & $(0.00002)$ & $(0.00009)$ & $(0.001)$ \\
\hline
\end{tabular}


Table 3. Continued

\begin{tabular}{|c|c|c|c|c|}
\hline \multirow{2}{*}{$\begin{array}{l}\text { Independent } \\
\text { variable }^{\text {d }}\end{array}$} & \multirow[b]{2}{*}{ Cow model } & \multicolumn{3}{|c|}{ Herd model } \\
\hline & & Mean & Variance & Skewness \\
\hline \multirow[t]{2}{*}{ Intercept } & $2.736 * * *$ & $1.509 * * *$ & 0.332 & -0.197 \\
\hline & $(0.254)$ & $(0.371)$ & $(0.216)$ & $(0.172)$ \\
\hline$M 1$ & $\begin{array}{c}0.0002 \\
(0.0009)\end{array}$ & & & \\
\hline \multirow[t]{2}{*}{$M 2$} & 0.035 & 0.043 & 0.123 & $1.111^{* * *}$ \\
\hline & $(0.038)$ & $(0.141)$ & $(0.149)$ & $(0.336)$ \\
\hline \multirow[t]{2}{*}{ M3 } & -0.005 & $0.212 * *$ & -0.033 & $-0.384^{*}$ \\
\hline & $(0.030)$ & $(0.06)$ & $(0.098)$ & $(0.218)$ \\
\hline \multirow[t]{2}{*}{$M 4$} & $-0.50^{* * *}$ & $-1.131 * *$ & $0.659 *$ & $2.379 * * *$ \\
\hline & $(0.103)$ & $(0.399)$ & $(0.372)$ & $(0.880)$ \\
\hline \multirow[t]{2}{*}{ M5 } & $-0.140 * *$ & 0.150 & -0.004 & 0.360 \\
\hline & $(0.041)$ & $(0.134)$ & $(0.139)$ & $(0.330)$ \\
\hline \multirow[t]{2}{*}{ M6 } & $0.157 * * *$ & 0.212 & 0.061 & $1.080^{* *}$ \\
\hline & $(0.050)$ & $(0.205)$ & $(0.204)$ & $(0.481)$ \\
\hline \multirow[t]{2}{*}{$M 7$} & $-0.107 * *$ & -0.073 & 0.137 & 0.298 \\
\hline & $(0.053)$ & $(0.217)$ & $(0.217)$ & $(0.487)$ \\
\hline \multirow[t]{2}{*}{ M8 } & $-0.157 * * *$ & -0.047 & 0.147 & $0.551 *$ \\
\hline & $(0.053)$ & $(0.231)$ & $(0.233)$ & $(0.549)$ \\
\hline \multirow[t]{2}{*}{$M 9$} & $-0.346 * * *$ & -0.048 & -0.056 & 1.122 \\
\hline & $(0.072)$ & $(0.276)$ & $(0.326)$ & $(0.728)$ \\
\hline \multirow[t]{2}{*}{$M 10$} & 0.058 & 0.029 & 0.091 & 0.539 \\
\hline & $(0.043)$ & $(0.154)$ & $(0.174)$ & $(0.404)$ \\
\hline \multirow[t]{2}{*}{$M 11$} & 0.010 & -0.126 & 0.102 & 0.520 \\
\hline & $(0.038)$ & $(0.135)$ & $(0.143)$ & $(0.330)$ \\
\hline \multirow[t]{2}{*}{$M 12$} & -0.043 & -0.198 & 0.026 & 0.151 \\
\hline & $(0.045)$ & $(0.161)$ & $(0.156)$ & $(0.362)$ \\
\hline \multirow[t]{2}{*}{$M 13$} & 0.004 & 0.220 & -0.237 & -0.005 \\
\hline & $(0.067)$ & $(0.215)$ & $(0.241)$ & $(0.676)$ \\
\hline \multirow[t]{2}{*}{ M14 } & $-0.122 * * *$ & 0.047 & -0.174 & 0.463 \\
\hline & $(0.051)$ & $(0.193)$ & $(0.189)$ & $(0.428)$ \\
\hline \multirow[t]{2}{*}{$M 15$} & -0.035 & $0.232^{*}$ & 0.149 & -0.260 \\
\hline & $(0.037)$ & $(0.133)$ & $(0.160)$ & $(0.434)$ \\
\hline \multirow[t]{2}{*}{ M16 } & $0.152 * * *$ & 0.226 & -0.074 & 0.438 \\
\hline & $(0.041)$ & $(0.145)$ & $(0.159)$ & $(0.367)$ \\
\hline \multirow[t]{2}{*}{$M 17$} & $-0.181 * * *$ & -0.044 & -0.179 & -0.092 \\
\hline & $(0.053)$ & $(0.167)$ & $(0.160)$ & $(0.394)$ \\
\hline \multirow[t]{2}{*}{$M 18$} & -0.022 & 0.092 & -0.059 & $-0.618^{* *}$ \\
\hline & $(0.035)$ & $(0.125)$ & $(0.127)$ & $(0.295)$ \\
\hline$M 19^{\circ}$ & $\begin{array}{c}-0.289 \\
(0.331)\end{array}$ & & & \\
\hline
\end{tabular}


Table 3. Continued

\begin{tabular}{|c|c|c|c|c|}
\hline \multirow{2}{*}{$\begin{array}{c}\text { Independent } \\
\text { variable }^{\mathrm{a}}\end{array}$} & \multirow[b]{2}{*}{ Cow model } & \multicolumn{3}{|c|}{ Herd model } \\
\hline & & Mean & Variance & Skewness \\
\hline \multirow[t]{2}{*}{$M 20$} & $-0.158 * * *$ & $-0.391 * * *$ & 0.141 & $0.770 * * *$ \\
\hline & $(0.044)$ & $(0.154)$ & $(0.144)$ & $(0.333)$ \\
\hline \multirow[t]{2}{*}{$M 21$} & $0.076 * * *$ & $0.209 * *$ & -0.113 & $0.574 * * *$ \\
\hline & $(0.029)$ & $(0.103)$ & $(0.108)$ & $(0.249)$ \\
\hline \multirow{2}{*}{$M 22$} & $-0.435 * * *$ & $-0.437 * * *$ & 0.069 & $-1.235^{* * *}$ \\
\hline & $(0.052)$ & $(0.165)$ & $(0.160)$ & $(0.347)$ \\
\hline \multirow[t]{2}{*}{$M 23$} & -0.066 & -0.094 & $0.366^{* *}$ & -0.114 \\
\hline & $(0.053)$ & $(0.180)$ & $(0.185)$ & $(0.404)$ \\
\hline \multirow[t]{2}{*}{$M 24$} & $-0.178 * * *$ & -0.138 & 0.297 & $0.826^{*}$ \\
\hline & $(0.061)$ & $(0.200)$ & $(0.216)$ & $(0.466)$ \\
\hline \multirow{2}{*}{$M 25$} & 0.065 & -0.044 & 0.202 & $-0.646^{* * *}$ \\
\hline & $(0.051)$ & $(0.174)$ & $(0.183)$ & $(0.432)$ \\
\hline \multirow[t]{2}{*}{$M 26$} & $0.224 * *$ & 0.185 & -0.132 & -0.607 \\
\hline & $(0.098)$ & $(0.317)$ & $(0.280)$ & $(0.725)$ \\
\hline \multirow[t]{2}{*}{$M 27$} & 0.163 & $1.168 * *$ & -0.392 & 0.914 \\
\hline & $(0.201)$ & $(0.577)$ & $(0.847)$ & $(2.160)$ \\
\hline \multirow[t]{2}{*}{$M 28$} & $-0.138 * * *$ & $-0.215^{*}$ & -0.085 & -0.103 \\
\hline & $(0.034)$ & $(0.110)$ & $(0.113)$ & $(0.269)$ \\
\hline \multirow[t]{2}{*}{$M 29$} & $-0.094 * * *$ & -0.105 & -0.131 & $-0.594^{* * *}$ \\
\hline & $(0.029)$ & $(0.098)$ & $(0.098)$ & $(0.223)$ \\
\hline \multirow[t]{2}{*}{ M30 } & $-0.92 * * *$ & 0.012 & 0.133 & 0.072 \\
\hline & $(0.030)$ & $(0.108)$ & $(0.116)$ & $(0.246)$ \\
\hline \multirow[t]{2}{*}{ M31 } & 0.014 & 0.046 & -0.072 & -0.085 \\
\hline & $(0.046)$ & $(0.150)$ & $(0.145)$ & $(0.334)$ \\
\hline \multirow[t]{2}{*}{$M 32$} & $0.133^{* * *}$ & -0.091 & -0.150 & $-0.479^{*}$ \\
\hline & $(0.039)$ & $(0.131)$ & $(0.137)$ & $(0.295)$ \\
\hline \multirow[t]{2}{*}{$M 33$} & $0.175 * * *$ & 0.126 & $0.324^{* *}$ & $0.591^{*}$ \\
\hline & $(0.042)$ & $(0.149)$ & $(0.144)$ & $(0.319)$ \\
\hline \multirow[t]{2}{*}{$M 34$} & 0.006 & 0.031 & -0.031 & -0.119 \\
\hline & $(0.012)$ & $(0.040)$ & $(0.042)$ & $(0.103)$ \\
\hline \multirow[t]{2}{*}{ M35 } & $0.037 * * *$ & 0.116 & 0.054 & $-0.228^{* * *}$ \\
\hline & $(0.014)$ & $(0.045)$ & $(0.045)$ & $(0.097)$ \\
\hline \multirow[t]{2}{*}{$P 1$} & 0.032 & $0.231^{*}$ & 0.085 & $0.487^{*}$ \\
\hline & $(0.033)$ & $(0.121)$ & $(0.123)$ & $(0.280)$ \\
\hline \multirow[t]{2}{*}{$P 2$} & -0.216 & -0.035 & -0.045 & 0.427 \\
\hline & $(0.037)$ & $(0.135)$ & $(0.150)$ & $(0.399)$ \\
\hline \multirow[t]{2}{*}{$P 3$} & 0.002 & $-0.131^{*}$ & 0.067 & -0.109 \\
\hline & $(0.018)$ & $(0.077)$ & $(0.072)$ & $(0.172)$ \\
\hline
\end{tabular}


Table 3. Concluded

\begin{tabular}{|c|c|c|c|c|}
\hline \multirow{2}{*}{$\begin{array}{c}\text { Independent } \\
\text { variable }^{\text {a }}\end{array}$} & \multirow[b]{2}{*}{ Cow model } & \multicolumn{3}{|c|}{ Herd model } \\
\hline & & Mean & Variance & Skewness \\
\hline \multirow[t]{2}{*}{$P 4$} & $0.005 * * *$ & 0.011 & 0.006 & -0.009 \\
\hline & $(0.002)$ & $(0.007)$ & $(0.007)$ & $(0.018)$ \\
\hline \multirow[t]{2}{*}{$P 5$} & $0.003^{* * *}$ & 0.002 & -0.002 & -0.006 \\
\hline & $(0.002)$ & $(0.007)$ & $(0.007)$ & $(0.017)$ \\
\hline \multirow[t]{2}{*}{$P 6$} & $-0.009 * * *$ & -0.015 & 0.001 & -0.006 \\
\hline & $(0.002)$ & $(0.007)$ & $(0.007)$ & $(0.019)$ \\
\hline \multirow[t]{2}{*}{$P 7$} & $-0.038 * * *$ & $-0.086^{* * *}$ & 0.014 & $0.108^{*}$ \\
\hline & $(0.008)$ & $(0.027)$ & $(0.028)$ & $(0.060)$ \\
\hline \multirow[t]{2}{*}{$P 8$} & $0.021 * * *$ & $0.047^{*}$ & 0.011 & 0.005 \\
\hline & $(0.007)$ & $(0.025)$ & $(0.024)$ & $(0.057)$ \\
\hline \multirow[t]{2}{*}{$P 9$} & $-0.083^{* * *}$ & -0.090 & -0.075 & 0.118 \\
\hline & $(0.027)$ & $(0.087)$ & $(0.090)$ & $(0.212)$ \\
\hline \multirow[t]{2}{*}{$L N$} & $0.265 * * *$ & $1.818^{* * *}$ & -0.468 & -1.053 \\
\hline & $(0.007)$ & $(0.672)$ & $(0.697)$ & $(1.551)$ \\
\hline \multirow[t]{2}{*}{$S L 2$} & $0.332 * * *$ & -0.619 & -0.165 & -0.419 \\
\hline & $(0.036)$ & $(0.761)$ & $(0.784)$ & (1.181) \\
\hline \multirow[t]{2}{*}{$S L 3$} & $0.927 * * *$ & 0.997 & 0.012 & $3.347^{*}$ \\
\hline & $(0.035)$ & $(0.719)$ & $(0.772)$ & $(1.775)$ \\
\hline \multirow[t]{2}{*}{$N O C$} & $0.004 * * *$ & $0.019 * * *$ & $-0.006^{*}$ & 0.011 \\
\hline & $(0.0008)$ & $(0.003)$ & $(0.003)$ & $(0.008)$ \\
\hline$B C A$ & $\begin{array}{c}-0.005^{* *} \\
(0.0009)\end{array}$ & & & \\
\hline \multirow[t]{2}{*}{$P L C$} & & $0.00001 * * *$ & -0.000005 & -0.000007 \\
\hline & & $(0.000004)$ & $(0.000005)$ & $(0.000001)$ \\
\hline adjusted $R^{2}$ & 0.3847 & 0.6937 & 0.1042 & 0.5563 \\
\hline
\end{tabular}

${ }^{a}$ See Table 2 for definitions of variables.

${ }^{b} \mathrm{SCC}$ is the log base 2 score. The average herd SCC is computed as:

Sum [test day milk yield/cow $\times$ (test day $\mathrm{SCC} /$ cow) ]

Sum [test day milk yield/cow)]

'Deleted from herd model due to collinearity.

*Significant at the 0.10 level

**Significant at the 0.05 level

$* * *$ Significant at the 0.01 level 
Milk yield is clearly negatively related over observed SCC levels, but milk yield responds to increasing SCC differently in the cow and herd models, as depicted in Figure 1. This difference indicates that a producer who monitors SCC levels from the bulk tank or some other aggregate measure could be unaware that the herd is producing less than its maximum potential. Both models report higher milk yields for larger herds (NOC). Milk yield decreases with the second and third stage of lactation (SL2 and SL3) in the cow model, but herd average milk yield increases with the percentage of the herd in those stages.

The model of the variance of the herd's milk yield has few significant parameters, but the model of the skewness has several significant parameters. A greater percentage of a herd in a second or later lactation is associated with an increasing left-hand skewness. ${ }^{6}$ An increasing right-hand skewness is associated with the percentage of the herd in the second and third stages of lactation. The size of the herd also significantly increases right-hand skewness, but with a very small magnitude.

\section{SCC and Management, Producer and Production Characteristics}

Among the expected results from the SCC equation in the cow model are that washing udders before milking has a large, negative effect on SCC, whether one washed with single-use paper towels $(M 6)$, newspapers $(M 7)$ or a hand-held sprayer (M9). $M 7$ and $M 9$ were also negative in the herd model, while $M 6$ was positive but not significant. Using a sanitizer in the washing solution $(M 10)$ is a common practice associated with higher SCC, though not significantly. Drying udders with single-use paper towels $(M 12)$ is highly recommended and is negative, though not significant in both models. Drying udders with a reusable sponge or cloth (M13) is thought to spread infections and is highly discouraged. $M 13$ is associated with increased SCC in both models, but significant in neither. Newspapers (M14) are often substituted for single-use paper towels for drying udders and are associated with significantly lower SCC in the cow model; $M 14$ is positive but not significant in the herd model. Changing inflations as needed rather than on a schedule (M15) is associated with lowered SCC in both models, significantly so in the herd model.

A premilking check into a strip cup (M17) is associated with a lower SCC in both the cow and herd models (not significant in the herd model). Producers who routinely take samples for culture $(M 20)$ of cows with clinical symptoms have significantly lower SCC levels in both models. Teat dipping after milking (M22) is highly recommended and has the largest significant negative impact on SCC in both models.

Information and formal and informal education are associated with lowered SCC. Regular visits (as opposed to emergency visits only) from veterinarians (M28), visits from Ontario Milk Marketing Board Udder Health Specialists (M29), the more years managing one's own farm $(P 6)$, and regularly attending extension seminars $(P 9)$ are all negatively related to $\mathrm{SCC}$. 


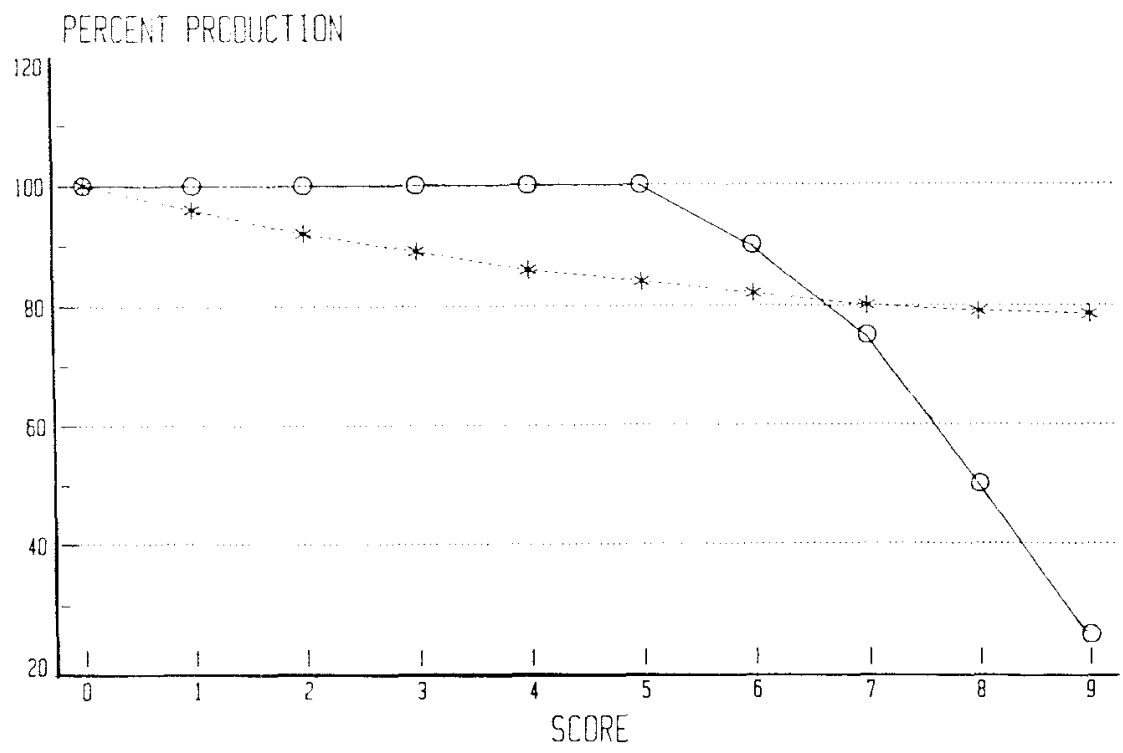

IIERD SCC COW SCC

Figure 1. Percentage of potential milk production for an individual cow $\left({ }^{*}\right)$ and for a herd (O) with increased SSC

Production characteristics are as expected or indeterminate. The number of lactations for a cow or the percentage of the herd in the second or later lactation $(L N)$ and the size of the herd (NOC) are positively related to SCC. SCC is thought to increase with the second and third stage of lactation or with the percentage of the herd in those stages (Natzke 1976). The cow model shows SCC increasing with stage of lactation, but the herd model has a positive relationship only for $S L 3$, though not significant in either stage. Larger herds are generally thought to have higher SCC, but there have been mixed results on the relationship between herd size and SCC (Howard et al 1987). As herd size in Ontario is continuing to grow, it is important to further explore that relationship.

Plate loop count (PLC), a bulk tank measure of bacteria in the milking system, is positively associated both milk yield and SCC in the herd equation. The PLC is not directly correlated with the SCC but, as an indicator of milk house hygiene, it is not unexpected to be positively associated with SCC. However, the positive sign in the mean milk yield equation is difficult to explain. Collinearity between PLC and breed class average (BCA) causes PLC to be deleted from the cow equations.

Unexpected results occur with some recommended and widely used practices. Reusable sponges or cloths are thought to spread infections but, when used 
for washing udders $(M 8)$, they are associated with lowered SCC in both models (significant in the cow model). ${ }^{7}$ When used for drying udders (M13), they have a positive, though not significant, paramater.

Treating infected cows with an antibiotic $(M 21)$ is recommended but is positive and significant in both models. The use of antibiotics at the end of a lactation (dry cow treatment) is recommended but has mixed results. Treating all quarters of all cows $(M 23)$ is the usual recommendation but it has a negative though not significant effect on SCC. Treating selected cows only (M24) has a larger (and significant in the cow model) negative effect on SCC. However, the selection criterion is not known. Treating only high SCC cows (M25) has mixed signs. Treating only cows that have been treated for mastitis in that lactation $(M 26)$ and treating only older cows (M27) are associated with higher SCC (M26 significant in the cow model, $M 27$ significant in the herd model).

It is generally assumed that an owner, as opposed to an employee, would treat the cows with greater care, resulting in lower stress and fewer injuries and therefore lower SCC. However, farms where owners did most of the milking $(P 1)$ had higher SCC and farms where employees did most of the milking had lower SCC (a mix of milking by owner and employees is the default). There may be increasing marginal returns to labor generated from specialization resulting in better herd health care, but confounding this result is the significant increase in SCC with the number of people on the farm $(P 8)$.

\section{Linear Moments Model}

Three practices and one production characteristic were unambiguously associated with lower SCC in all three moments. Regular visits by veterinarians (M28) or by Ontario Milk Marketing Board Udder Health Specialists (M29) and bringing increased SCC to the attention of a veterinarian (M32) are associated with a lower mean SCC, lower variance and increased (decreased) right- (left-) hand skewness. The percentage of the herd in the second stage of lactation is also negative in all three moments.

Six practices and three production characteristics are associated with increased SCC in all three moments. Using straw for bedding (M2), using a sanitizer in the washing solution (M10), always drying udders before milking (M11), bringing emergency/acute cases to the attention of a veterinarian (M30) and considering mastitis when culling cows (M33) are associated with increased SCC. M2 is expected to increase SCC; the other practices are not. SCC increases with the number of peope working on the farm $(P 8)$, but increased $\mathrm{SCC}$ is also found on farms where the owner does most of the milking $(P 1)$. Percentage of the herd in the third stage of lactation is also associated with increased SCC (SL3).

Interpreting practices with mixed responses across the moments is ambiguous. For example, doing a premilking check into a paper towel (M18) is the only practice with a positive response in the first moment and negative responses in 
the second and third moments (significant only in the third moment). Given those responses, it is possible to classify it as a mean-preserving, risk-reducing practice. However, $M 18$ is also negative and not significant in the cow model. The response in the cow model may be a clearer indication that $M 18$ may be a risk-reducing input than an evaluation of its moments.

\section{Economic Values of Management Practices}

Marginal input costs (MICs) and marginal value products (MVPs) for recommended (or recommended against, in the case of a reusable sponge to wash udders) practices are reported in Table 4. MVPs are greater than MICs for the three methods reported for washing udders, for single-use paper towels to dry udders, milking machine inflations changed by the farmer, teat dipping after milking and dry cow treatment. Costs are greater than returns for using a sanitizer in the washing solution, drying udders with a reusable sponge or cloth and having milking-machine inflations changed as needed by a service company. The MVP for dry cow treatment of selected cows is much greater than its MIC, but the MVP of dry cow treatment to all quarters of all cows is only slightly greater than its MIC. ${ }^{8}$

MVPs under the proposed multiple-component pricing (MCP) system are not significantly different from the MVPs estimated under fluid milk pricing, as reported in Table 4. These results indicate that the proposed MCP system will not significantly change the economic benefits of mastitis control practices.

Table 4. Predicted marginal value products from the statistical model and marginal input costs of selected management practices from the producers

\begin{tabular}{lcrr} 
& & \multicolumn{2}{c}{ Marginal value products } \\
\cline { 3 - 5 } & \multicolumn{2}{c}{$\begin{array}{c}\text { Marginal } \\
\text { input } \\
\text { cost }\end{array}$} & \multicolumn{2}{c}{ pricing } & MCP \\
\cline { 3 - 5 } Practice & 5.15 & 26.63 & 27.26 \\
\hline Individual paper towels used to wash udders & 0.58 & 26.63 & 27.05 \\
Reusable sponge/cloth used to wash udders & & 29.65 & 58.19 \\
Hand-held sprayer used to wash udders & 2.89 & -9.81 & -8.05 \\
Sanitizer used in the washing solution & 5.14 & 7.16 & 8.94 \\
Single-use paper towels used to dry udders & 0.58 & -0.77 & -1.12 \\
Reusable sponge/cloth used to dry udders & & & \\
Milking-machine inflations changed as needed & & 5.80 & 7.17 \\
by service company & 6.62 & 5.80 & 7.17 \\
by farmer & 8.15 & 75.53 & 74.10 \\
Teat dipping after milking & 8.27 & 11.06 & 12.92 \\
Dry cow treatment to all cows & 8.27 & 30.25 & 31.30 \\
Dry cow treatment to selected cows & &
\end{tabular}




\section{SUMMARY AND DISCUSSION}

The survey reports that only a third of the producers used all five recommended mastitis control practices. It is possible that the producers are unaware of the economic returns from the practices. It is also possible that a producer will adopt a new practice only in response to a problem. Either way, these results indicate that there is room for Ontario dairy producers to improve their mastitis management practices.

The estimated relationship between milk yield and SCC quantifies their expected negative relationship. However, a comparison of milk yield equations for individual cows and for herd average milk production indicates that producers who depend on bulk tank SCC or some other aggregate measure of SCC as an indicator of herd udder health may be unaware that their herd is producing at less than its potential.

The practices recommended by the National Mastitis Council (NMC) (i.e., hygienic washing and drying of udders before milking, regular milking-machine maintenance, teat dipping after milking, dry cow treatment on all cows, culling cows with chronic mastitis and milking infected cows last) are generally found to be effective in lowering SCC, and returns from the practices are greater than their costs. However, the common practice of using a sanitizer in the washing solution and having a service company change milking machine inflations as needed are not economically beneficial.

The results raise questions about dry cow treatment. The NMC recommends treating all quarters of all cows at drying off. Producers in this sample who followed that recommendation are not associated with significantly lower SCC, but producers who treated selectively do have significantly lower SCC. At least one previous study has had questionable results on dry cow treatment of all quarters of all cows (Howard et al 1987). The unexpected results from dry cow treatment (and other unexpected results as well) could be due to spurious correlation: producers may have adopted the practices in response to a mastitis problem rather than the practice contributing to the problem. However, it is also possible that dry cow treatment of all quarters of all cows is in fact selecting for antiobioticresistant bacteria, resulting in higher SCC. If the latter is the case, an optimum selection criterion needs to be developed for selective dry cow treatment that will minimize antibiotic use (and thus cost) while targeting antibiotic use where it is most needed. Selection criteria that will minimize antibiotic use are especially important, given consumers' concerns about food quality and food safety.

Given that the cow is the basic production unit on a dairy farm, modeling of production responses appears to be best done at the cow level. The individual cow SCC provides more accurate information about a herd's udder health than does the bulk tank SCC. The greater loss at low SCC levels found in the cow model indicates that producers may not be aware of lost production if they depend 
upon a bulk tank SCC to monitor their herd's udder health. Similarly, the cow model provides a better estimate of the effect of a management practice on the cow's SCC. Even though the herd model explains more variation in SCC, the cow model has more than twice as many significant parameters than the herd model. The purpose of the model in this study is to estimate the impact of a practice, not forecast a future value; hence, a significant parameter is preferred to better explanation of the variance. However, the moment-generating approach does indicate the possibility of risk-reducing inputs or herd health practices that affect higher moments while leaving the mean unchanged. Given the complex biological functions in livestock production. the moment-generating approach may yet provide insights not obtainable from other analytical methods.

A limitation of this study is the use of cross-section data, which are not sufficient for determining the effects of practices over time or optimum selection criteria for dry cow treatment. A richer (and much more expensive) data set would contain the same cow, herd and producer information collected for this study, but would collect that information over time. Such a data set is required to determine the effects of the management practices over time and to develop optimum selection criteria for dry cow treatment.

\section{NOTES}

'Somatic cells include epithelial cells, which are sloughed off as part of a normal lactation, and leucocytes, which are produced to destroy bacteria. Somatic cell levels are inversely related to udder health.

'A Journal reviewer pointed out that unknown output prices can also cause uncertainty about the marginal effect of an input or a practice.

${ }^{3}$ Other practices often mentioned include proper milking techniques, maintaining a clean, dry environment and using inorganic bedding.

${ }^{+}$The California mastitis test (CMT) indicates the level of somatic cells in milk, and hence the likelihood of a subclinical infection. through a chemical reaction between a milk sample and a testing compound. The CMT is not as exact a measure as the SCC. but the results of the CMT are available immediately, whereas the SCC requires a laboratory.

SSurvey instruments are available from the senior author.

${ }^{6} \mathrm{~A}$ positive parameter in the third-moment equation means the distribution is increasing skewness to the right or an increase in the right-hand tail of the distribution. A negative parameter means the distribution is increasing skewness to the left or an increase in the left-hand tail of the distribution.

${ }^{7} \mathrm{~A}$ Journal reviewer suggested that the massaging action rather than the sponge itself is beneficial for udder health.

"A Journal reviewer suggested that a caveat may be in order: the estimated marginal products are not signficant for six of the 11 practices reported in Table 4 (sanitizer in the washing solution, single-use paper towels to dry udders, reusable sponge/cloth to dry udders, milking-machine inflations changed as needed and dry cow treatment to all cows). The other five practices are significant at the 0.01 level. 


\section{ACKNOWLEDGMENT}

This study was funded in part by a grant from the Ontario Milk Marketing Board and by the Ontario Ministry of Agriculture and Food. The assistance of the Ontario Dairy Herd Improvement Corporation is gratefully acknowledged. The paper benefited greatly from the comments of three Journal reviewers. All remaining errors are the responsibility of the authors.

\section{REFERENCES}

Anderson, J. 1973. Sparse data, climatic variability and yield uncertainty in response analysis. American Journal of Agricultural Economics 55: 77-82.

Antle, J. M. 1983. Testing the stochastic structure of production: A flexible momentbased approach. Journal of Business Economics and Statistics 1: 192-201.

Antle, J. M. and W. J. Goodger. 1984. Measuring stochastic technology: The case of Tulare milk production. American Journal of Agricultural Economics 66: 342-50.

Appleman, R. D., G. A. Rowe and O. D. Forker. 1965. Relationship between milk production and incidence of low-level mastitis as indicated by California mastitis test. Journal of Dairy Science 48: 829.

Batra, R. 1974. Resource allocation in a general equilibrium model of production under uncertainty. Journal of Economic Theory 8: 50-63.

Batra, T. R. 1986. Relationship of somatic cell concentration with milk yield in dairy cows. Canadian Journal of Animal Science 66: 607.

Dillon, J. W. 1977. The Analysis of Response in Crop and Livestock Production. New York: Pergamon Press.

Dohoo, I. R., A. H. Meek and S. W. Martin. 1984. Somatic cell counts in bovine milk: Relationships to production and clinical episodes of mastitis. Canadian Journal of Comparative Medicine 48: 135-39.

Forester, T. L., U. S. Ashworth and L. O. Leudecke. 1967. Relationship between California mastitis test and composition of milk from opposite quarters. Journal of Dairy Science 50: 675-82.

Fuller, W. Stochastic fertilizer production functions for continuous corn. Journal of Farm Economics 47: 105-19.

Griliches, Z. 1957. Hybrid corn: An exploration in the economics of technological change. Econometrica 25: 501-22.

Howard, W. H., Thomas O. Knight, C. Richard Shumway, Robert W. Blake and Michael A. Tomaszewski 1987. Information and herd health management practices in Texas dairies. Southern Journal of Agrictural Economics, 19(2): 1.

Jones, G. M., R. E. Pearson, G. A. Clasgaugh and C. W. Heald. 1984. Relationships between somatic cell counts and milk production. Journal of Dairy Science 67: 1823-31.

Kirk, John H. and Paul C. Bartlett. 1988. Economic impact of mastitis in Michigan holstein dairy herds using computerized records system. Agri Practice (1): 3.

Leslie, K. E., I. R. Dohoo and A. H. Meek. 1983. Somatic cells counts in bovine milk. Compendium of Continuing Eduation for Practicing Veterinarians 6: 5601.

Natzke, R. P. 1976. The economics of mastitis control. In Proceedings of the Large Herd Management Symposium. Gainesville: University of Florida, January. 
Natzke, R. P. 1981. Elements of mastitis control. Journal of Dain Science 641: 1431. Ontario Milk Marketing Board. 1985. MCP proposal. Mississauga. Ontario, May. Philpot, W. N. 1984. Mastitis Management. Oak Brook. Ill.: Babson Brothers.

Robertas, R. F. and G. E. Shook. 1982. Relationship between lactation measures of somatic cell concentration and milk yield. Journal of Dairy Science 65: 419-25.

Salsberg, E., A. H. Meek and S. W. Martin. 1984. Somatic cell counts: Associated factors and relationship to production. Canadian Journal of Comparative Medicine 48: $251-57$.

Smith, G. J. 1988. Somatic cell count penalty program proposal in Ontario. Paper presented at the County and District Milk Committees Executive Conference. Mississauga, Ontario, October

Tyler, J. W., M. C. Thurmond and L. Lasslo. 1989. Relationship between test-day measures of somatic cell count and milk production in California dairy cows. Canadian Journal of Veterinarian Research 53: 182-87. 